\title{
FERMENTATION OF SACCHARIDES ISSUED FROM A DAIRY INDUSTRY BY A GENETICALLY MODIFIED STRAIN OF ESCHERICHIA COLI INTO ACETOIN AND 2,3-BUTANEDIOL
}

\author{
DAVID FERNÁNDEZ-GUTIERREZ ${ }^{1,2}$, MARC VEILLETTE ${ }^{1}$, ANTONIO AVALOS RAMIREZ ${ }^{3}$, \\ ANNE GIROIR-FENDLER ${ }^{2}$, NATHALIE FAUCHEUX ${ }^{1} \&$ MICHÈLE HEITZ $^{1}$ \\ ${ }^{1}$ Department of Chemical and Biotechnological Engineering, Faculty of Engineering, \\ Université de Sherbrooke, Canada \\ ${ }^{2}$ Université Lyon 1- IRCELYON: Institut de Recherche sur la Catalyse et l'Environnement de Lyon, France \\ ${ }^{3}$ Centre National en Électrochimie et en Technologies Environnementales, Canada
}

\begin{abstract}
Whey, which usually shows a high biological oxygen demand and a high chemical oxygen demand, should be treated before being rejected as waste water. The valorization of whey by chemical/physical treatments already exists. Some bioprocesses are also currently developed to transform whey into, for example, biogas. However, new performing green processes are still in development in order to obtain chemical products able to replace those issued from petroleum resources like acetoin (A) and 2,3butanediol (2,3-BD), two important chemical platform molecules. The main objective of the present study was to evaluate the potential use of glucose, galactose and a lactose source derived from a dairy industry to produce $\mathrm{A}$ and 2,3-BD (ABD). The main issue of the natural producer bacteria of 2,3-BD such as Klebsiella pneumoniae or K. oxytoca during the fermentation of saccharides is their biosafety level since they are pathogen. In this way, non-pathogenic bacteria can be genetically modified to produce ABD from saccharides. In the present study, a genetically modified strain of Escherichia coli K12 MG1655 (non-pathogenic strain) was used. Two monosaccharides (glucose and galactose issued from lactose) at three concentrations $(12.5,25$ and $50 \mathrm{~g} / \mathrm{L}$ ) were fermented using $0.5 \mathrm{~L}$ flasks for $120 \mathrm{~h}$ at $37^{\circ} \mathrm{C}, 1 \mathrm{~atm}$, initial $\mathrm{pH} 7.4,100 \mathrm{rpm}$ and $10 \%(\mathrm{v} / \mathrm{v})$ of inoculum in a synthetic culture medium (M9). All experiments showed that the fermentation of galactose was less efficient than the one of glucose (the $\mathrm{ABD}$ yields were around $25 \%, 40 \%$ and $35 \%$ lower compared to those obtained fermenting glucose at $12.5,25$ and $50 \mathrm{~g} / \mathrm{L}$ at $96 \mathrm{~h}$ respectively). The highest $\mathrm{ABD}$ yield was 0.26 (g/g glucose), obtained at $96 \mathrm{~h}$ in the presence of $25 \mathrm{~g} / \mathrm{L}$ of glucose. The ABD yields issued from glucose and galactose were compared with those derived from a dairy industry lactose.
\end{abstract}

Keywords: monosaccharide, glucose, galactose, lactose, whey, M9 culture medium, biovalorisation.

\section{INTRODUCTION}

Whey is a dairy effluent generated during the cheese manufacturing. It contains lactose (the main part of the dry matter of whey), proteins, etc. Due to its high biological (BOD) and chemical (COD) oxygen demands, it is necessary to treat the whey before releasing it in the environment. The valorization of whey via biotechnology has as objectives a) to decrease the BOD and COD values, and b) to generate products like 2,3-butanediol (2,3-BD). Bacteria like Enterobacter cloacae and Klebsiella pneumoniae are able to hydrolyze and transform saccharides like lactose into acetoin (A) and 2,3-BD. Although these bacteria are pathogenic, they are considered as the best natural 2,3-BD producers. Therefore, other non-pathogenic bacterial strains are being developed for the hydrolysis and the fermentation of saccharides like lactose. In this way, a non-pathogenic strain like, for example, Escherichia coli K12 MG1655 would be a good option. However, E. coli cannot produce 2,3-BD. Genetic modifications in the $E$. coli strain have to be performed in order to transfer the metabolic pathway from a natural 2,3-BD producer like E. cloacae. 
Escherichia coli K12 MG1655 presents several advantages compared to the previous natural producers of 2,3 BD strains: i) has a biosafety level 1 (non-pathogenic), ii) can consume a wide range of saccharides like glucose and galactose ( 2 monosaccharides issued from whey lactose), and iii) is easily modified to host metabolic pathways from other microorganisms [1], [2]. In order to produce A and 2,3-BD (ABD), E. coli has to transform both monosaccharides into pyruvic acid (PA), which occurs by different pathways: glycolysis for glucose and Leloir pathway plus glycolysis for galactose [3], [4].

Afterwards, the PA is transformed into $\alpha$-acetolactate by $\alpha$-acetolactate synthase (ALS). Then, $\alpha$-acetolactate is transformed into A by means of $\alpha$-acetolactate decarboxylase (ALDC) enzyme. Finally, A is converts into 2,3-BD by 2,3-butanediol dehydrogenase (BDH) enzyme [5]. Fig. 1 shows the metabolic pathway to obtain A and 2,3-BD from glucose and galactose.

In the present study, a genetically modified strain of E. coli K12 MG1655 (E. coli JFR1) was used to host the metabolic pathway of 2,3-BD from E. cloacae in order to test the ability of $E$. coli JFR1 to produce ABD from glucose and galactose. Three monosaccharide concentrations $(12.5,25$ and $50 \mathrm{~g} / \mathrm{L})$ were fermented at $10 \%(\mathrm{v} / \mathrm{v})$ of inoculum, $37^{\circ} \mathrm{C}, 1 \mathrm{~atm}$, initial $\mathrm{pH} 7.4$ and $100 \mathrm{rpm}$ and the ABD yields were compared. The culture medium, M9, was used in a preliminary study and was selected as the best culture medium to obtain ABD from glucose [8]. Lactose was also fermented, and the ABD yield was compared with those from glucose and galactose.

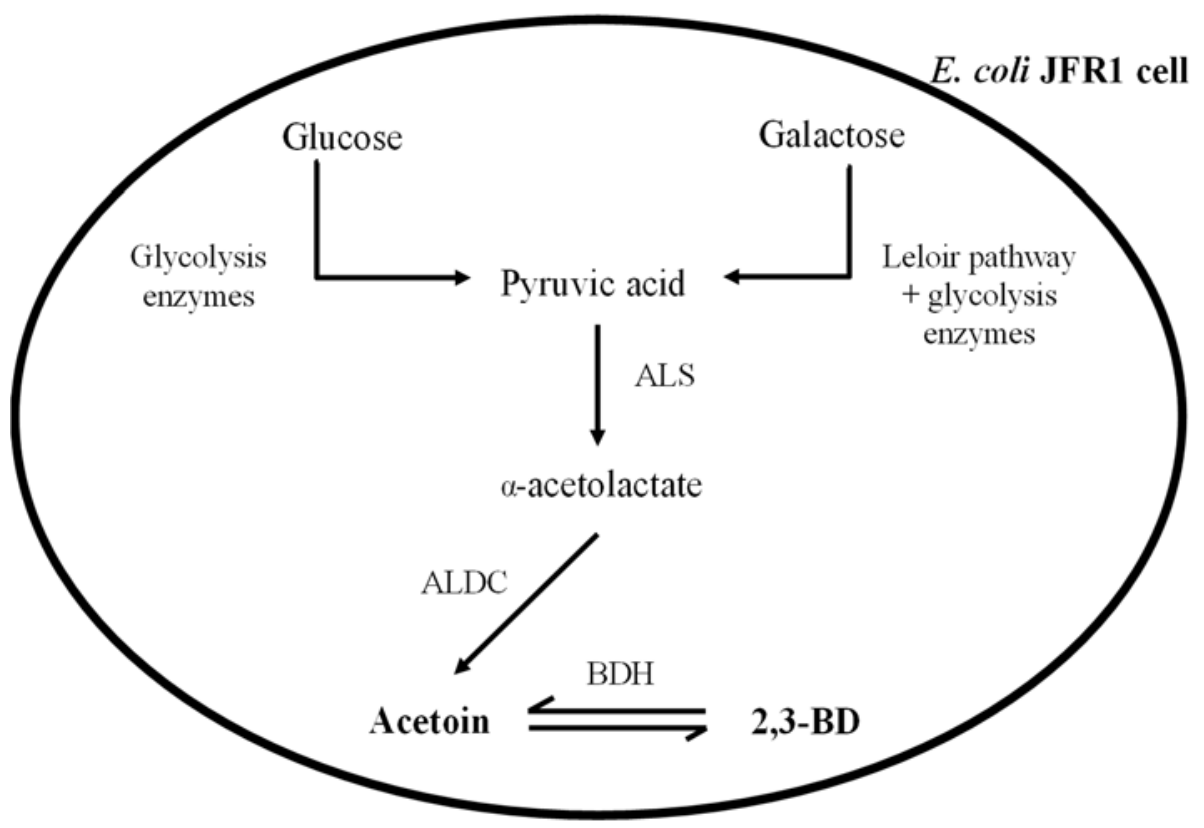

Figure 1: Metabolic pathway to produce 2,3-BD from glucose and galactose fermentation in the presence of a genetically modified strain of Escherichia coli. Relevant reactions to transform pyruvic acid into 2,3-BD are represented by the names of the corresponding enzymes from Enterobacter cloacae: $\alpha$-acetolactate synthase (ALS), $\alpha$-acetolactate decarboxylase (ALDC) and 2,3-butanediol dehydrogenase (BDH) [3]-[7]. 


\section{MATERIALS AND METHODS}

\subsection{Microorganisms}

The genetically modified strain of E. coli K12 MG1655 hosts the metabolic pathway of 2,3$\mathrm{BD}$ to produce $\mathrm{ABD}$ from $E$. cloacae. The biosynthetic pathway of fermentative D-lactate dehydrogenase $(l d h A)$ was blocked to avoid the formation of lactic acid. The modified strain was $E$. coli $\mathrm{K} 12 \mathrm{MG} 1655 / \mathrm{D} l d h A+$ budABC, named as $E$. coli JFR1. The conservation of $E$. coli JFR1 was performed at $-81^{\circ} \mathrm{C}$ in a blend $(50: 50, \mathrm{v} / \mathrm{v})$ of glycerol and lysogeny broth (LB) culture medium.

\subsection{Culture media and conditions}

Escherichia coli JFR1 was grown in LB culture medium since it is suitable for recombinant E. coli strains [9]. The composition of LB culture medium was as follows: $10 \mathrm{~g} / \mathrm{L}$ of tryptone, $5 \mathrm{~g} / \mathrm{L}$ of yeast extract, $10 \mathrm{~g} / \mathrm{L}$ of sodium chloride $(\mathrm{NaCl})$ and distilled water [10]. The $\mathrm{pH}$ of LB for growing E. coli JFR1 was adjusted at 6.5. The fermentation of glucose, galactose and lactose by $E$. coli JFR1 was tested using M9, which was made as follows: $12.8 \mathrm{~g} / \mathrm{L}$ of sodium hydrogen phosphate heptahydrate $\left(\mathrm{Na}_{2} \mathrm{HPO}_{4} \cdot 7 \mathrm{H}_{2} \mathrm{O}\right), 3 \mathrm{~g} / \mathrm{L}$ of potassium dihydrogen phosphate $\left(\mathrm{KH}_{2} \mathrm{PO}_{4}\right), 1 \mathrm{~g} / \mathrm{L}$ of ammonium chloride $\left(\mathrm{NH}_{4} \mathrm{Cl}\right), 0.5 \mathrm{~g} / \mathrm{L} \mathrm{NaCl}, 15 \mathrm{~g} / \mathrm{L}$ urea $\left(\left(\mathrm{NH}_{2}\right)_{2} \mathrm{CO}\right), 0.49 \mathrm{~g} / \mathrm{L}$ of magnesium sulfate heptahydrate $\left(\mathrm{MgSO}_{4} \cdot 7 \mathrm{H}_{2} \mathrm{O}\right)$ and $0.01 \mathrm{~g} / \mathrm{L}$ of calcium chloride $\left(\mathrm{CaCl}_{2}\right)$ and distilled water [8].

The seed culture medium was prepared as follows: a sample of E. coli JFR1 from the conservation blend was taken with a tip and mixed with $10 \mathrm{~mL}$ of fresh $\mathrm{LB}$ medium in a test tube $(15 \mathrm{~mL})$. The test tube was incubated overnight at $37^{\circ} \mathrm{C}$ (pre-culture medium). Then, 2 $\mathrm{mL}$ of the pre-culture medium were transferred into a $0.5 \mathrm{~L}$ Erlenmeyer flask containing 0.2 $\mathrm{L}$ of fresh LB medium and incubated in a rotary shaker incubator (Fermentation Design inc, Allentown, PA) at $37^{\circ} \mathrm{C}, 1 \mathrm{~atm}$, initial $\mathrm{pH} 6.5$ and $100 \mathrm{rpm}$ to reach a bacterial population of $6.5 \times 10^{8}$ colony-forming unit $(\mathrm{CFU}) / \mathrm{mL}$ in $9 \mathrm{~h}$. The seed culture medium was used to inoculate M9 culture medium.

All fermentations were performed in triplicate at $10 \%(\mathrm{v} / \mathrm{v})$ of inoculum, $37^{\circ} \mathrm{C}, 1 \mathrm{~atm}$, initial $\mathrm{pH} 7.4$ and $100 \mathrm{rpm}$ in $0.5 \mathrm{~L}$ flask $(0.2 \mathrm{~L}$ of working volume).

\subsection{Analytical methods}

The analysis of glucose, galactose, lactose, 2,3-BD and A was determined by high performance liquid chromatography (HPLC) as shown in a previous study [8].

\subsection{Statistical analysis}

The ABD formation may be influenced by the type and concentration of the substrate. In this way, the effect of glucose, galactose and lactose concentration on ABD yield was statistically determined by means of an analysis of variance (ANOVA) at $p<0.05$. In addition, Dixon's $\mathrm{Q}$ test was carried out to estimate and rule out the outlier values of ABD yield at a confidence level of $95 \%$ [11].

\section{RESULTS AND DISCUSSION}

The fermentation of glucose and galactose was performed in M9 culture medium in order to produce ABD by $E$. coli JFR 1 . The effect of 3 concentrations $(12.5,25$ and $50 \mathrm{~g} / \mathrm{L})$ of glucose and galactose were tested. 
Fig. 2 (a) and (b) shows the glucose and galactose conversion for 3 initial concentrations $(12.5,25$ and $50 \mathrm{~g} / \mathrm{L})$ of glucose and galactose ([Glu $]_{0}$ and $[\mathrm{Gal}]_{0}$, respectively) as a function of time. At $24 \mathrm{~h}$, for a $[\mathrm{Glu}]_{0}$ of $12.5 \mathrm{~g} / \mathrm{L}$, the glucose conversion was $100 \%$, whereas for a $[\mathrm{Glu}]_{0}$ of 25 and $50 \mathrm{~g} / \mathrm{L}$ conversions were $77 \%$ and $56 \%$, respectively. Glucose conversion was $100 \%$ for a $[\mathrm{Glu}]_{0}$ of $25 \mathrm{~g} / \mathrm{L}$ at $72 \mathrm{~h}$, while the conversion was $70 \%$ fermenting $50 \mathrm{~g}$ glucose/L. The maximum conversion for a $[\mathrm{Glu}]_{0}$ of $50 \mathrm{~g} / \mathrm{L}$ was $77 \%$, obtained at $120 \mathrm{~h}$ (Fig. 2(a)).

Similarly, the galactose conversion was $100 \%$ for a [Gal $]_{0}$ of $12.5 \mathrm{~g} / \mathrm{L}$ at $24 \mathrm{~h}$; whereas it was 75 and $55 \%$ in the presence of 25 and $50 \mathrm{~g} / \mathrm{L}$ of galactose, respectively. At $72 \mathrm{~h}$, the galactose conversion was $96 \%$ using a $[\mathrm{Gal}]_{0}$ of $25 \mathrm{~g} / \mathrm{L}$ and it was $72 \%$ for a $[\mathrm{Gal}]_{0}$ of $50 \mathrm{~g} / \mathrm{L}$. The maximum galactose conversion for a $[\mathrm{Gal}]_{0}$ of $50 \mathrm{~g} / \mathrm{L}$ was $76 \%$, which was reached at $120 \mathrm{~h}$ (Fig. 2(b)).

As observed in Fig. 2(a) and (b), the trend of glucose and galactose conversions was similar for both monosaccharides whatever the concentration used. On the other hand, the use of a high concentration ( $50 \mathrm{~g}$ of monosaccharide/L) led to a low conversion $(77 \%)$ even after $120 \mathrm{~h}$ of fermentation. No change in galactose conversion was observed after $96 \mathrm{~h}$ of
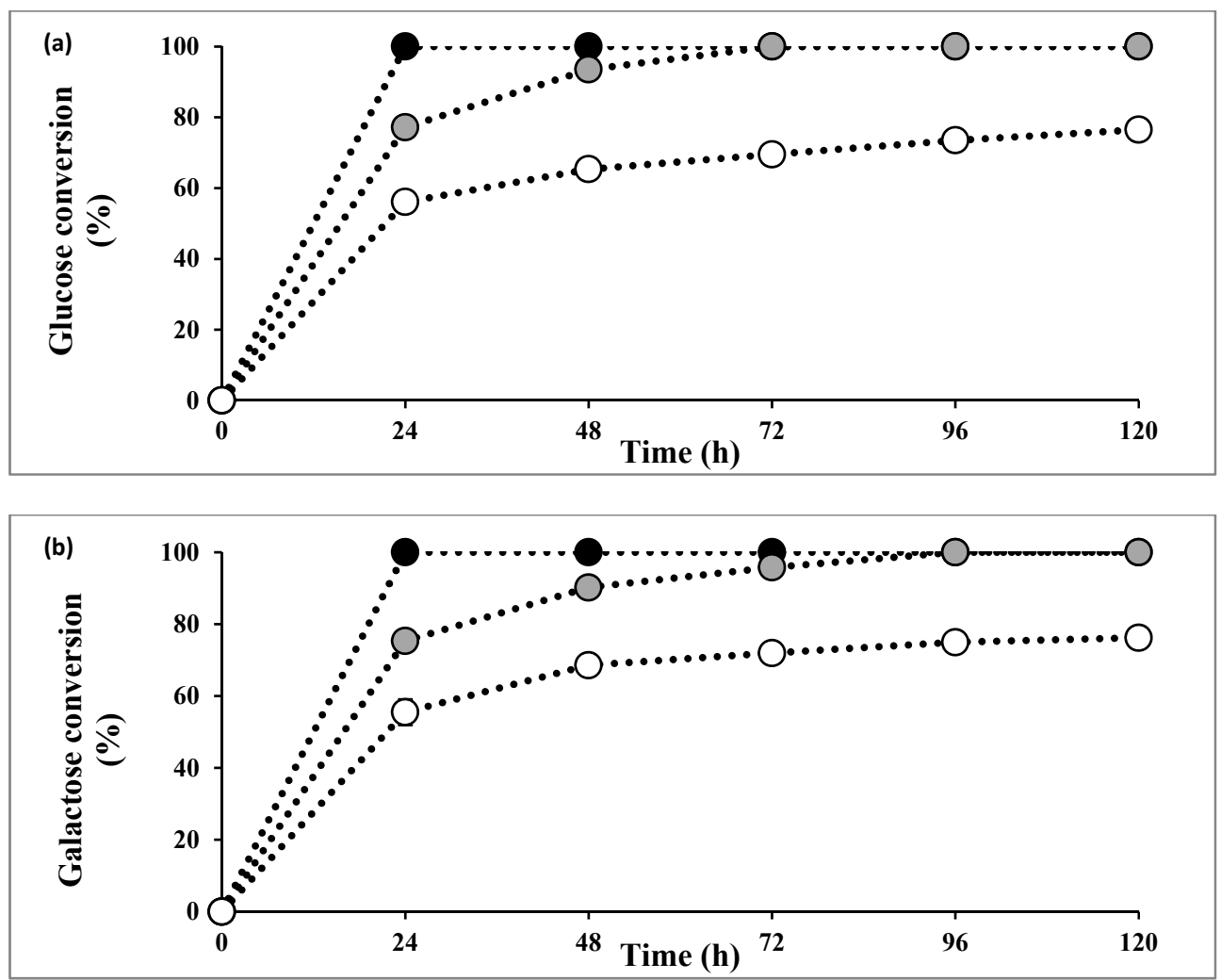

Figure 2: Glucose (a) and galactose (b) conversion as a function of time. Results are means $\pm \mathrm{SD}$ of 3 replications performed in flasks at $37^{\circ} \mathrm{C}, 1 \mathrm{~atm}$, initial $\mathrm{pH} 7.4,100 \mathrm{rpm}$ and $10 \%(\mathrm{v} / \mathrm{v})$ of inoculum in the presence of $E$. coli JFR1 in M9 culture medium $(0.2 \mathrm{~L}$ of working volume) with $12.5(\bullet), 25(\bullet)$ and $50(\mathrm{\circ}) \mathrm{g} / \mathrm{L}$ of monosaccharide. 
fermentation. Bacteria present a threshold concentration to which the bacterial population might be affected if it is exceeded, causing a slower bacterial growth as suggested by Chan et al. [12]. In the case of E. coli JFR1, this threshold concentration seems to be between 25 and $50 \mathrm{~g} / \mathrm{L}$ since the $100 \%$ conversion was reached using $25 \mathrm{~g} / \mathrm{L}$ for both monosaccharides between 72 and $96 \mathrm{~h}$; however, it was not achieved for $50 \mathrm{~g} / \mathrm{L}$ at $120 \mathrm{~h}$ reaching a plateau after $96 \mathrm{~h}$.

Fig. 3 (a) and (b) shows the ABD yield for 3 initial concentrations (12.5, 25 and $50 \mathrm{~g} / \mathrm{L})$ of glucose and galactose $\left([\mathrm{Glu}]_{0}\right.$ and $\left.[\mathrm{Gal}]_{0}\right)$, respectively as a function of time. For the $[\mathrm{Glu}]_{0}$ of $12.5 \mathrm{~g} / \mathrm{L}$, the maximum ABD yield $(0.18 \mathrm{~g} / \mathrm{g}$ glucose $)$ was obtained at $24 \mathrm{~h}$ and remained nearly constant up to $120 \mathrm{~h}$. For a $[\mathrm{Glu}]_{0}$ of $25 \mathrm{~g} / \mathrm{L}$, the ABD yield increased reaching a plateau at $0.26 \mathrm{~g} / \mathrm{g}$ glucose at $96 \mathrm{~h}$ and remained constant up to $120 \mathrm{~h}$; whereas with the [Glu $]_{0}$ of $50 \mathrm{~g} / \mathrm{L}$, the ABD yield increased up to $0.15 \mathrm{~g} / \mathrm{g}$ glucose at $120 \mathrm{~h}(\mathrm{p}<0.05)$ as shown in Fig. 3(a).

In the case of galactose, for a $[\mathrm{Gal}]_{0}$ of $12.5 \mathrm{~g} / \mathrm{L}$, the ABD yield reached a plateau at 0.13 g/g galactose at $24 \mathrm{~h}$ (Fig. 3(b)) and then remained constant. Using a [Gal $]_{0}$ of $25 \mathrm{~g} / \mathrm{L}$, the ABD yield increased up to $0.16 \mathrm{~g} / \mathrm{g}$ galactose $(\mathrm{p}<0.05)$ at $72 \mathrm{~h}$ and remained constant until
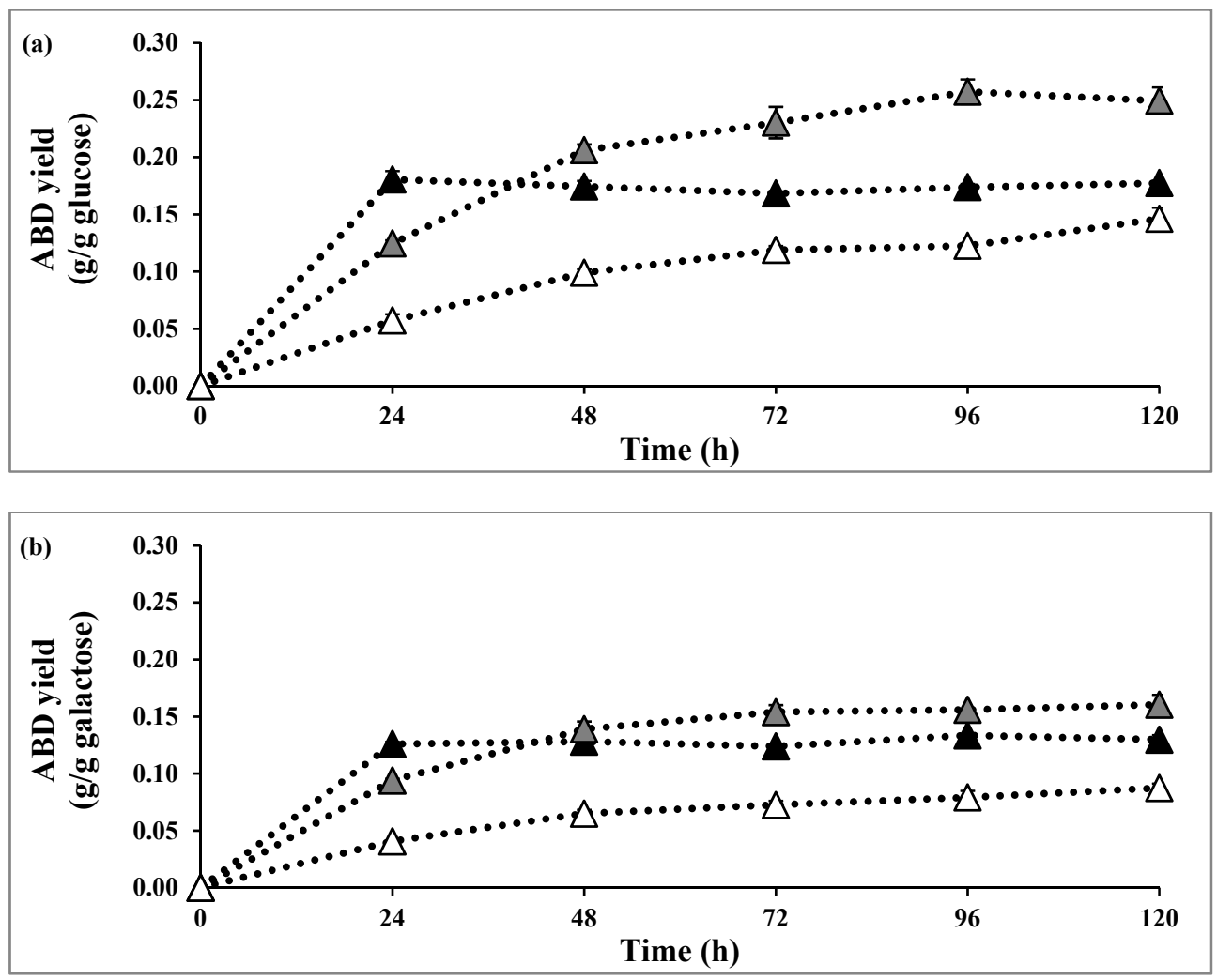

Figure 3: ABD yield from glucose (a) and galactose (b) as a function of time. Results are means $\pm \mathrm{SD}$ of 3 replications performed in flasks at $37^{\circ} \mathrm{C}, 1 \mathrm{~atm}$, initial $\mathrm{pH} 7.4$, $100 \mathrm{rpm}$ and $10 \%(\mathrm{v} / \mathrm{v})$ of inoculum in the presence of E. coli JFR1 in M9 culture medium $(0.2 \mathrm{~L}$ of working volume) at $12.5(\mathbf{\Delta}), 25(\Delta)$ and $50(\Delta) \mathrm{g} / \mathrm{L}$ of monosaccharide. 
the end of the experiment $(120 \mathrm{~h})$; whereas in the presence of $[\mathrm{Gal}]_{0}$ of $50 \mathrm{~g} / \mathrm{L}$, the ABD yield increased to $0.08 \mathrm{~g} / \mathrm{g}$ galactose at $96 \mathrm{~h}$ and remained nearly constant up to $120 \mathrm{~h}(\mathrm{p}<0.05)$.

Comparing the 3 glucose concentrations, the maximum ABD yield was $0.26 \mathrm{~g} / \mathrm{g}$ glucose at $96 \mathrm{~h}$ in the presence of $25 \mathrm{~g} / \mathrm{L}$ of glucose, which was around $48 \%$ and $110 \%$ higher compared to the maximum obtained using 12.5 and $50 \mathrm{~g} / \mathrm{L}$ of glucose, respectively. In the case of galactose, the highest ABD yield $(0.16 \mathrm{~g} / \mathrm{g}$ galactose $)$ was reached in the presence of a [Gal $]_{0}$ of $25 \mathrm{~g} / \mathrm{L}$ at $72 \mathrm{~h}$. However, this ABD yield $(0.16 \mathrm{~g} / \mathrm{g}$ galactose) was only improved by $25 \%$ compared to the one at $12.5 \mathrm{~g} / \mathrm{L}$ of galactose, obtained at $24 \mathrm{~h}$, a fermentation time 3 -fold shorter. Therefore, the best ratio galactose concentration-fermentation time in order to obtain ABD was $12.5 \mathrm{~g} / \mathrm{L}$ since this yield was around $0.13 \mathrm{~g} / \mathrm{g}$ galactose at $24 \mathrm{~h}$.

The difference between both monosaccharides in terms of ABD yield is that the use of glucose was more efficient than galactose since the ABD yields were $30 \%, 65 \%$ and $55 \%$ higher using glucose at $12.5,25$ and $50 \mathrm{~g} / \mathrm{L}$ respectively compared to galactose at $96 \mathrm{~h}$. As mentioned previously, the use of a high monosaccharide concentration $(50 \mathrm{~g} / \mathrm{L})$ might lead to the inhibition of the bacterial growth, which affects the formation of ABD as suggested by Chan et al. [12], Krämer [13] and Priya et al. [14]. This phenomenon is clearly observed in the present study at $50 \mathrm{~g} / \mathrm{L}$ of monosaccharide in the presence of $E$. coli JFR 1 since the ABD yield at a $[\mathrm{Glu}]_{0}$ of $25 \mathrm{~g} / \mathrm{L}$ was more than double compared to the one obtained at a $[\mathrm{Glu}]_{0}$ of $50 \mathrm{~g} / \mathrm{L}$ at $96 \mathrm{~h}$; the ABD yield was near $100 \%$ higher at a $[\mathrm{Gal}]_{0}$ of $25 \mathrm{~g} / \mathrm{L}$ compared to a $[\mathrm{Gal}]_{0}$ of $50 \mathrm{~g} / \mathrm{L}$ at $96 \mathrm{~h}$.

As observed in Fig. 3 (a) and (b), the ABD yield reached a maximum and was nearly constant whatever the monosaccharide and concentration used. As shown in Fig. 1, the diol $(2,3-\mathrm{BD})$ is an end product which is in equilibrium with $\mathrm{A}$, its precursor. Acetoin is transformed into 2,3-BD by the BDH enzyme. Mazumdar et al. [6] suggested that 2,3-BD can be used by $E$. coli and, thus, can be transformed into A. This might explain why using $E$. coli JFR1, the ABD yield was nearly constant in the present study after reaching its maximum.

To the best of our knowledge, E. coli has not been used to ferment glucose and galactose in order to obtain ABD. However, other studies reported a comparison of glucose and galactose in the presence of bacteria like Enterobacter aerogenes, Geobacillus XT15 Paenibacillus polymyxa and Saccharomyces cerevisiae [15]-[18]. For example, Xiao et al. [18] reported an ABD yield of 0.34 and $0.21 \mathrm{~g} / \mathrm{g}$ monosaccharide (ABD yield calculated from the data provided by the authors) fermenting $20 \mathrm{~g} / \mathrm{L}$ of glucose and galactose respectively at $55^{\circ} \mathrm{C}$ and $170 \mathrm{rpm}$ (pH and time non-defined) in the presence of Geobacillus sp. XT15 (5\% $(\mathrm{v} / \mathrm{v})$ of inoculum). Although the yields reported by this author were superior to those obtained in the present study, the difference of ABD yield between both monosaccharides was 1.6-fold higher using glucose than galactose; a similar difference in terms of ABD yield in the presence of $E$. coli JFR 1 using $25 \mathrm{~g} / \mathrm{L}$ of monosaccharide at $96 \mathrm{~h}$ was also observed. Therefore, the use of glucose seems to be more suitable than galactose in order to produce ABD in the presence of E. coli JFR1.

Table 1 presents the ABD yields obtained after fermentation of 3 substrates, i.e. glucose, galactose and lactose (lactose being the whey disaccharide composed of galactose and glucose) at 2 concentrations: 12.5 and $25 \mathrm{~g}$ (substrate) $/ \mathrm{L}$ at $10 \%(\mathrm{v} / \mathrm{v})$ of inoculum, $37^{\circ} \mathrm{C}, 1$ atm, initial pH 7.4 and $100 \mathrm{rpm}$ in $0.5 \mathrm{~L}$ flask $(0.2 \mathrm{~L}$ of working volume). Lactose was only fermented at 12.5 and $25 \mathrm{~g} / \mathrm{L}$ since these 2 concentrations of glucose and galactose gave the highest ABD yields.

As can be seen in Table 1, whatever the concentration of 12.5 or $25 \mathrm{~g}$ (substrate)/L at 24 $\mathrm{h}$ of fermentation, the ABD yield from lactose is similar to the one from glucose (for example, at $24 \mathrm{~h}$, and for a saccharide concentration of $12.5 \mathrm{~g} / \mathrm{L}$, the ABD yield is $0.18 \mathrm{~g} / \mathrm{g}$ saccharide 
Table 1: $\quad$ ABD yield (g/g saccharide) for glucose, galactose and lactose as a function of fermentation time. Results are means \pm SD of 3 replications performed in flasks at $37^{\circ} \mathrm{C}, 1 \mathrm{~atm}$, initial $\mathrm{pH} 7.4,100 \mathrm{rpm}$ and $10 \%(\mathrm{v} / \mathrm{v})$ of inoculum in the presence of $E$. coli JFR1 in M9 culture medium ( $0.2 \mathrm{~L}$ of working volume) with 12.5 and $25 \mathrm{~g} / \mathrm{L}$ of saccharide.

\begin{tabular}{|c|c|c|c|c|c|c|}
\hline \multicolumn{4}{|c|}{ Saccharide concentration: $12.5 \mathrm{~g} / \mathrm{L}$} & \multicolumn{3}{c|}{ Saccharide concentration: $25 \mathrm{~g} / \mathrm{L}$} \\
\hline Time (h) & Glucose & Galactose & Lactose & Glucose & Galactose & Lactose \\
\hline 24 & 0.18 & 0.13 & 0.18 & 0.12 & 0.09 & 0.12 \\
\hline 72 & 0.17 & 0.12 & 0.17 & 0.23 & 0.16 & 0.19 \\
\hline
\end{tabular}

(glucose or lactose); the ABD yield relative to galactose being always inferior to the ABD yields obtained with glucose or lactose. A similar behavior is observed at $72 \mathrm{~h}$ of fermentation for $12.5 \mathrm{~g}$ lactose/L. An ABD yield of $0.19 \mathrm{~g} / \mathrm{g}$ lactose, superior by $19 \%$ is noticed at $25 \mathrm{~g}$ lactose/L and $72 \mathrm{~h}$ compared to that one using galactose. These ABD yields were higher than those obtained in other studies while fermenting lactose in the presence of bacteria belonging to risk level 1. For instance, Kallbach et al. [19] fermented $57 \mathrm{~g} / \mathrm{L}$ of lactose in the presence of Bacillus atrophaeus, B. licheniformis, B.mojavensis and B. vallismortis at $39^{\circ} \mathrm{C}$ and 700 $\mathrm{rpm}$ ( $\mathrm{pH}$ not provided) for $47 \mathrm{~h}$. The ABD yields ( $\mathrm{g} / \mathrm{g}$ lactose) using these strains were 0.00 (B. atrophaeus and B. mojavensis), 0.01 (B. licheniformis) and 0.08 (B. vallismortis). On the other hand, during the fermentation of lactose in presence of $E$. coli JFR1, galactose present in lactose does not seem to affect the ABD yield. Lactose issued from whey has also been fermented but for confidentiality reasons, the promising results cannot be presented yet [20].

\section{CONCLUSION}

The present study was based on the fermentation of 2 monosaccharides in order to produce acetoin and 2,3-butanediol (ABD) in the presence of a genetically modified strain of Escherichia coli: $E$. coli JFR1. Glucose and galactose at different concentrations $(12.5,25$ and $50 \mathrm{~g} / \mathrm{L})$ in $\mathrm{M} 9$ culture medium at $10 \%(\mathrm{v} / \mathrm{v})$ of inoculum, $37^{\circ} \mathrm{C}, 1 \mathrm{~atm}$, initial $\mathrm{pH} 7.4$ and $100 \mathrm{rpm}$ in $0.5 \mathrm{~L}$ flask $(0.2 \mathrm{~L}$ of working volume) were fermented.

The use of whatever glucose concentration provided better results in terms of ABD yield than the fermentation of galactose. The ABD yields were between $30 \%$ and $65 \%$ higher in the presence of glucose for the range of concentrations tested compared to galactose at $96 \mathrm{~h}$. The highest ABD yield was $0.26 \mathrm{~g} / \mathrm{g}$ glucose at $96 \mathrm{~h}$ and $25 \mathrm{~g} / \mathrm{L}$ of glucose; whereas the best $\mathrm{ABD}$ yield was $0.16 \mathrm{~g} / \mathrm{g}$ galactose at $72 \mathrm{~h}$ and $25 \mathrm{~g} / \mathrm{L}$ of galactose. The ABD yields obtained during the fermentation of glucose or lactose were near similar at $24 \mathrm{~h}$ and $72 \mathrm{~h}$ under the same operating conditions.

This study demonstrated particularly that galactose can be used by E. coli JFR1 in order to produce ABD. Hence, an in-depth study using galactose should be considered in the presence of E. coli JFR1 with the aim of improving the ABD yield. On the other hand, the current study has provided evidences that lactose can be transformed by a green bioprocess into $\mathrm{ABD}$ in the presence of $E$. coli JFR 1 and thus whey has a huge potential as a lactose source to be valorized.

\section{ACKNOWLEDGEMENTS}

Michèle Heitz is grateful to Fond Québécois de la Recherche sur la Nature et les Technologies (FRQNT) in partnership with MAPAQ-NOVALAIT (Innovation en Production et en Transformation Laitières) for the grant attributed to the research program "Développement d'une biotechnologie verte innovatrice pour valoriser des résidus fromagers". Michèle Heitz 
would also like to thank the Natural Sciences and Engineering Research Council of Canada (NSERC) for a financially contribution at the end of the study. The authors are grateful to the laboratory technicians (Department of chemical and biotechnological engineering of Université de Sherbrooke) Isabelle Arsenault and Valérie Larouche for their support and help. The authors would like to particularly thank Pr. Sébastien Rodrigue and the master student Jean-François Rousseau (Department of biology of Université de Sherbrooke) for providing the genetically modified strain E. coli JFR1. Finally, authors would like to thank the local dairy industry Lactantia Parmalat (Victoriaville, Quebec, Canada) for providing the industrial samples of whey.

\section{REFERENCES}

[1] International Genetically Engineered Machine (iGEM), Safety/Risk group guide. Online. http://2014.igem.org/Safety/Risk_Group_Guide. Accessed on: 6 Aug. 2018.

[2] Tong, Y.J., Ji, X.J., Shen, M.Q., Liu, L.G., Nie, Z.K. \& Huang, H., Constructing a synthetic constitutive metabolic pathway in Escherichia coli for (R, R)-2,3-butanediol production. Applied Microbiology and Biotechnology, 100(2), pp. 637-647, 2016. DOI: 10.1007/s00253-015-7013-3.

[3] Lazar, Z., Gamboa-Meléndez, H., Crutz-Coq, A.M., Neuvéglise, C. \& Nicaud, J.M., Awakening the endogenous Leloir pathway for efficient galactose utilization by Yarrowia lipolytica. Biotechnology for Biofuels, 8(1), p. 185, 2015.

DOI: 10.1186/s13068-015-0370-4.

[4] Xu Y. et al., Systematic metabolic engineering of Escherichia coli for high-yield production of fuel bio-chemical 2,3-butanediol. Metabolic Engineering, 23, pp. 2233, 2014. DOI: 10.1016/j.ymben.2014.02.004.

[5] Xiao, Z. \& Lu, J.R., Strategies for enhancing fermentative production of acetoin: a review. Biotechnology Advances, 32(2), pp. 492-503, 2014.

DOI: 10.1016/j.biotechadv.2014.01.002.

[6] Mazumdar, S., Lee, J. \& Oh, M.K., Microbial production of 2,3 butanediol from seaweed hydrolysate using metabolically engineered Escherichia coli. Bioresource Technology, 136, pp. 329-336, 2013. DOI: 10.1016/j.biortech.2013.03.013.

[7] Xu Q. et al., Metabolic engineering of Escherichia coli for efficient production of (3R)acetoin. Journal of Chemical Technology and Biotechnology, 90(1), pp. 93-100, 2015. DOI: $10.1002 /$ jctb.4293.

[8] Fernández-Gutierrez, D., Veillette, M., Giroir-Fendler, A., Ávalos Ramirez, A., Faucheux, N. \& Heitz, M., Biovalorization of glucose in four culture media and effect of the nitrogen source on fermentative alcohols production by Escherichia coli. Environmental Technology, pp. 1-11, 2018. DOI: 10.1080/09593330.2018.1494751.

[9] Maniatis, T., Fritsch, E.F. \& Sambrook, J.F., Molecular Cloning: A Laboratory Manual, 3rd ed., Cold Spring Harbor: New York, p. 545, 2001.

[10] Berney, M., Weilenmann, H.U., Ihssen, J., Bassin, C. \& Egli, T., Specific growth rate determines the sensitivity of Escherichia coli to thermal, UVA, and solar disinfection. Applied and Environmental Microbiology, 72(4), pp. 2586-2593, 2006.

DOI: 10.1128/AEM.72.4.2586-2593.2006

[11] Rorabacher, D.B., Statistical treatment for rejection of deviant values: critical values of Dixon's "Q" parameter and related subrange ratios at the $95 \%$ confidence level. Analytical Chemistry, 63(2), pp. 139-146, 1991. DOI: 10.1021/ac00002a010.

[12] Chan, S., Jantama, S.S., Kanchanatawee, S. \& Jantama, K., Process optimization on micro-aeration supply for high production yield of 2,3-butanediol from maltodextrin 
by metabolically-engineered Klebsiella oxytoca. PLOS ONE 11(9), pp 1-20, 2016. DOI: 10.1371/journal.pone.0161503.

[13] Krämer, R., Bacterial stimulus perception and signal transduction: Response to osmotic stress. The Chemical Record, 10(4), pp. 217-229, 2010.

DOI: $10.1002 /$ tcr.201000005.

[14] Priya, A., Dureja, P., Talukdar, P., Rathi, R., Lal, B. \& Sarma, P.M., Microbial production of 2,3-butanediol through a two-stage $\mathrm{pH}$ and agitation strategy in $150 \mathrm{~L}$ bioreactor. Biochemical Engineering Journal, 105, pp. 159-167, 2016. DOI: 10.1016/j.bej.2015.09.016.

[15] Choi, E.J. et al., Enhanced production of 2,3-butanediol in pyruvate decarboxylasedeficient Saccharomyces cerevisiae through optimizing ratio of glucose/galactose. Biotechnology Journal, 11(11), pp. 1424-1432, 2016. DOI: 10.1002/biot.201600042.

[16] Jiang, L.Q., Fang, Z., Zhao, Z.L., He, F. \& Li, H.B., 2,3-butanediol and acetoin production from enzymatic hydrolysate of ionic liquid-pretreated cellulose by Paenibacillus polymyxa. BioResources, 10(1), pp. 1318-1329, 2015. DOI: 10.15376/biores.10.1.1318-1329.

[17] Jung, M.Y., Ng, C.Y., Song, H., Lee, J. \& Oh, M.K., Deletion of lactate dehydrogenase in Enterobacter aerogenes to enhance 2,3-butanediol production. Applied Microbiology and Biotechnology, 95(2), pp. 461-469, 2012.

DOI: $10.1007 / \mathrm{s} 00253-012-3883-9$.

[18] Xiao, Z. et al., Thermophilic fermentation of acetoin and 2,3-butanediol by a novel Geobacillus strain. Biotechnology for Biofuels, 5(1), p. 88, 2012.

DOI: 10.1186/1754-6834-5-88.

[19] Kallbach, M., Horn, S., Kuenz, A. \& Prüße, U., Screening of novel bacteria for the 2,3-butenediol production. Applied Microbiology and Biotechnology, 101(3), pp. 1025-1033, 2016. DOI: 10.1007/s00253-016-7849-1.

[20] Fernández-Gutierrez, D., Biovalorization of whey into 2,3-butanediol by fermentation. PhD thesis, Université de Sherbrooke, pp. 1-131, Jul. 2018. 